\title{
STUDI PENGARUH JARI-JARI DALAM MAGNET TERHADAP TEGANGAN GENERATOR AKSIAL PADA BAHAN CAKRAM AKRILIK
}

\author{
Pebri Prihatmoko*, F. Danang Wijaya, dan Suharyanto \\ Departemen Teknik Elektro dan Teknologi Informasi Fakultas Teknik \\ Universitas Gadjah Mada \\ Submitted: 30-11-2017; Revised: 16-08-2018; Accepted: 23-11-2018
}

\begin{abstract}
The high cost of making rotor discs is one aspect that becomes an obstacle in the implementation of axial generator research. This study aims to compare acrylic discs with wooden discs in terms of axial generator output voltage and production costs, so that further research can use alternative discs with lower cost. This study uses an experimental method, where this method is used to find existing variables. On a generator with an acrylic disc, the average voltage is 16.6 volts with a manufacturing cost of 151,500 rupiah. Whereas on generator with wood disc, the average voltage is 17.2 volts with a manufacturing cost of 48,750 rupiah. Thus wood disc can be an alternative material in making cheap axial generator rotor discs.
\end{abstract}

Keywords: Acrylic Discs; Magnetic Flux; Magnet Permeability; Neodymium Magnet; Wood Discs.

\begin{abstract}
ABSTRAK
Biaya pembuatan cakram rotor yang tinggi merupakan salah satu aspek yang menjadi hambatan dalam implementasi penelitian generator aksial. Penelitian ini bertujuan untuk membandingkan cakram akrilik dengan cakram kayu berdasarkan tegangan keluaran generator aksial dan biaya produksinya, sehingga penelitian selanjutnya bisa menggunakan cakram alternatif yang biaya pembuatannya lebih murah. Penelitian ini menggunakan metode eksperimen, dengan mengidentifikasi pengaruh perlakuan variabel tertentu terhadap variabel lain dalam kondisi yang terkendali. Generator dengan cakram akrilik menghasilkan tegangan keluaran rata-rata 16,6 volt dengan biaya pembuatan sebesar 151.500 rupiah. Sedangkan generator dengan cakram kayu menghasilkan tegangan keluaran rata-rata sebesar 17,2 volt dengan biaya pembuatan sebesar 48.750 rupiah. Dengan demikian cakram kayu dapat menjadi alternatif bahan dalam implementasi pembuatan cakram rotor generator aksial yang murah.
\end{abstract}

Kata Kunci: Cakram Akrilik; Cakram Kayu; Fluk Magnet; Magnet Neodimium; Permeabilitas Magnet.

*Corresponding author: fibriprihatmoko123@gmail.com

Copyright (C) 2019 THE AUTHOR(S). This article is distributed under a Creative Commons Attribution-Share Alike 4.0 International license. Jurnal Teknosains is published by the Graduate School of Universitas Gadjah Mada. 


\section{PENGANTAR}

Sejarah mesin listrik pertama kali bermula pada tahun 1831 ketika Faraday membuat mesin axial pertama kali [1]. Prototipe pertama mesin listrik axial berbentuk cakram dengan nama Cakram Faraday. Kontruksi mesin listrik tipe cakram ini juga di patenkan di U.S paten dengan nomor No. 405858 dengan nama Elektro Magnetik Motor dan dipublikasikan pada tahun 1889.

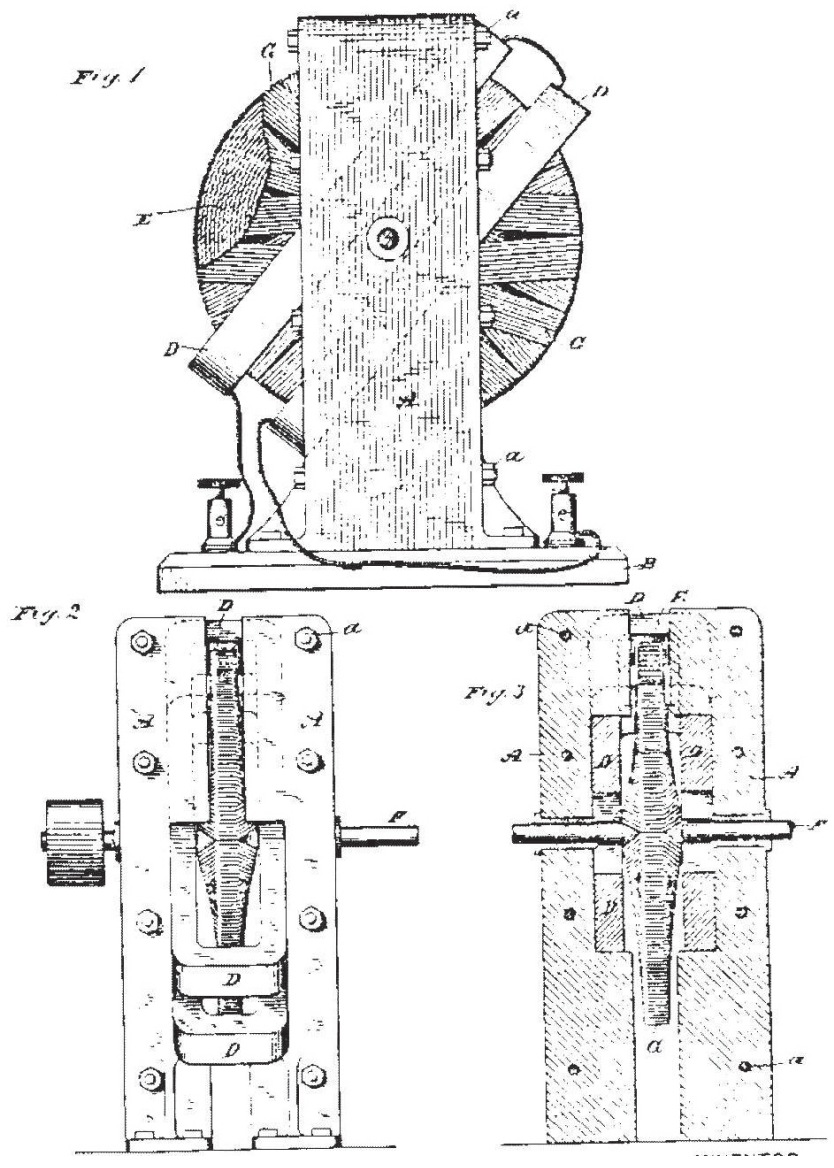

Gambar 1.

Cakram faraday

Sumber: Axial flux permanent magnet brushless machine, (2004).

Pada permulaan desain mesin fluks aksial menemui kendala-kendala antara lain dalam mengatasi gaya tarik menarik antarkutub magnet yang sangat kuat pada rotor, kesulitan dalam fabrikasi seperti memotong slot dengan inti yang di laminasi, kesulitan dalam merakit mesin, dan menjaga agar celah udara memiliki jarak yang konstan serta biaya yang sangat tinggi dalam pembuatan inti stator yang di laminasi [1].

Sistem eksitasi magnet permanen pertama diterapkan pada mesin-mesin listrik pada awal tahun 1830. Penemuan Alnico pada tahun 1931, barium ferit pada tahun 1950 dan penemuan bahan Neodium Iron
Boron (NdFeB) pada tahun 1983 menjadi daya dorong untuk menggunakan magnet permanen sebagai sistem eksitasi pada mesin aksial. Untuk penelitian-penelitian berikutnya, seperti penelitian yang di lakukan oleh Kostas Latoufis dengan judul "Design of Axial Flux Permanent Magnet Generators Using Various Magnetic Materials in Locally Manufactured Small Wind Turbines" menggunakan magnet neodium tipe N40 dan Feritte C8 [2]. Penelitian ini membandingkan dari segi biaya, efisiensi, dan berat antara generator yang menggunakan magnet neodium dengan generator yang menggunakan Feritte C8. 
PEBRI PRIHATMOKO, F. DANANG WIJAYA, DAN SUHARYANTO STUDI PENGARUH JARI-JARI DALAM MAGNET TERHADAP TEGANGAN GENERATOR AKSIAL ....

Tabel 1.

Perbandingan generator menggunakan magnet N40 dan Ferrite C8.

\begin{tabular}{c|c|c}
\hline Magnetic Material & NdFeB N40 & Ferrite C8 \\
\hline Rated Power & $840 \mathrm{~W}$ & $840 \mathrm{~W}$ \\
\hline Number of poles & 12 & 16 \\
\hline Number of coils & 9 & 12 \\
\hline Magnet dimensions & $30 \times 46 \times 10 \mathrm{~mm}$ & $50 \times 50 \times 20 \mathrm{~mm}$ \\
\hline Design cut-in & $215 \mathrm{RPM}$ & $215 \mathrm{RPM}$ \\
\hline Battery Voltage & $48 \mathrm{~V}$ & $25.8 \mathrm{~kg}$ \\
\hline Total Mass & $12.5 \mathrm{~kg}$ & $10.7 \mathrm{dm} 3$ \\
\hline Total Volume & $3.9 \mathrm{dm} 3$ & $99 €$ \\
\hline Magnets' cost & $240 €$ & $219 €$
\end{tabular}

Pada penelitian yang di lakukan oleh Zbigniew Goryca, dengan judul "Generators with permanent magnets used in small wind power plants" [3]. Pada penelitian ini membandingkan antara vertikal axis wind turbin (VAWT) generator 500 watt dengan 30 kutub magnet permanen dan horizontal axis wind turbine (HAWT) generator $10 \mathrm{KW}$ dengan 48 kutub magnet permanen.

Tabel 2.

Perbandingan generator VAWT dengan HAWT

\begin{tabular}{l|l|l}
\hline \multicolumn{2}{c}{ Generator type } & \multicolumn{2}{c}{ VAWT } & \multicolumn{1}{c}{ HAWT } \\
\hline Power & $500 \mathrm{~W}$ & $\mathrm{~kW}$ \\
\hline Output voltage & $3 \times 24 \mathrm{~V}$ & $3 \times 230 \mathrm{~V}$ \\
\hline Frequency & $50 \mathrm{~Hz}$ & $50 \mathrm{~Hz}$ \\
\hline Rotational speed & $200 \mathrm{rpm}$ & $125 \mathrm{rpm}$ \\
\hline Magnetic pole & 30 & 48 \\
\hline
\end{tabular}

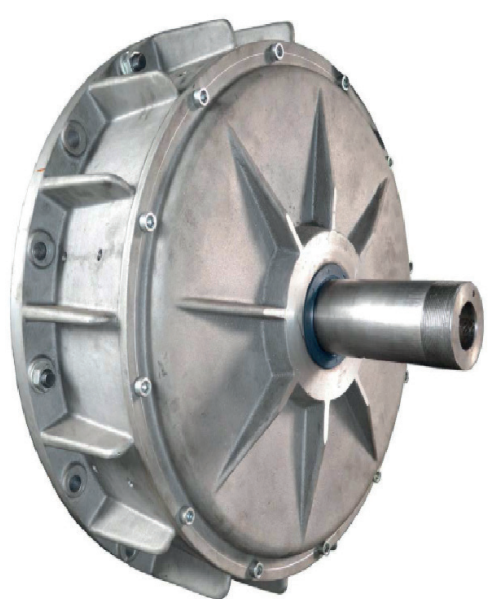

Gambar 2.

Generator HAWT 10 KW

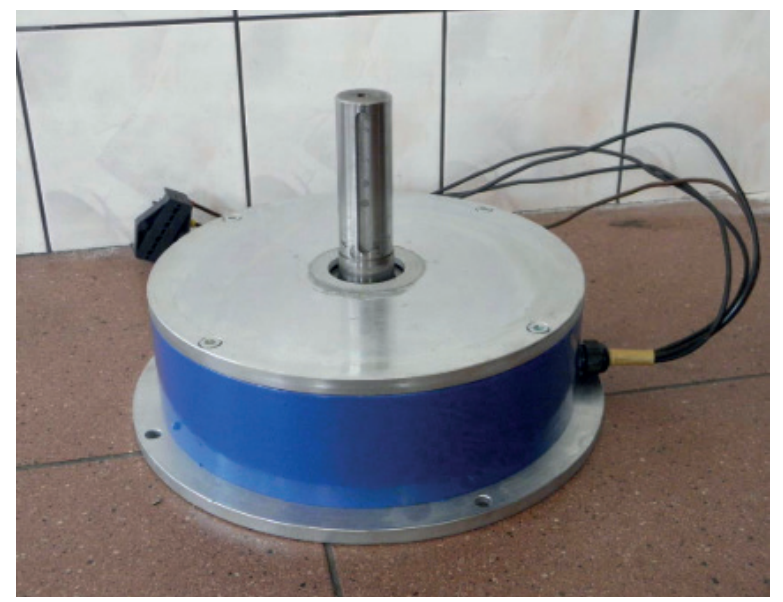

Gambar 3. Generator VAWT 500 watt.

Sumber: Generators with permanent magnets used in small wind power plant, (2015). 
Pada penelitian yang di lakukan oleh $\mathrm{M}$. Chirca dengan judul "Analysis of Innovative Design Variations for Double-Sided Coreless-Stator Axial-Flux Permanent-Magnet Generators in MicroWind Power Applications" [4] menggunakan 24 pasang magnet dari bahan ferrite. Penelitian ini merupakan bentuk pengembangan dari AFPM dan coil diinduksi dari dua sisi.

Tabel 3.

Spesifikasi Generator AFPM Dua Sisi

\begin{tabular}{l|l}
\hline \multicolumn{1}{c|}{ Design data } & \multicolumn{1}{c}{ Value } \\
\hline Number of poles & 24 \\
\hline Number of coils & 18 \\
\hline Inner diameter [mm] & 170 \\
\hline Outer diameter [mm] & 370 \\
\hline Stator thickness [mm] & 10 \\
\hline Rotor-disk thickness [mm] & 50 \\
\hline Axial length [mm] & 112 \\
\hline Airgap clearance [mm] & 2 \\
\hline PM remanence [T] & 0,4 \\
\hline Number of stator-winding phases & 3 \\
\hline
\end{tabular}

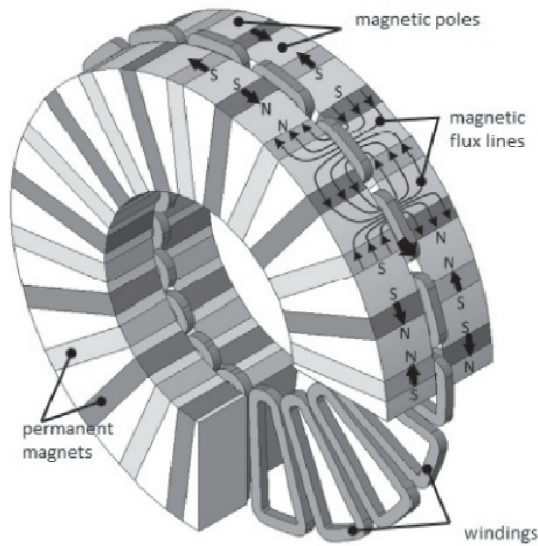

Gambar 4.

AFPM dengan 24 kutub magnet ferrite. Sumber: Analysis of innovative design variations for permanent-magnet generators in micro-wind power application, 2014.

Pada penelitian yang di lakukan oleh VV Parlikar dengan judul "An Axial-Flux Permanent Magnet (AFPM) Generator for Defence Applications - Paradigm Shift in Electrical Machine" menggunakan bahan besi lunak sebagai cakram rotor [5].

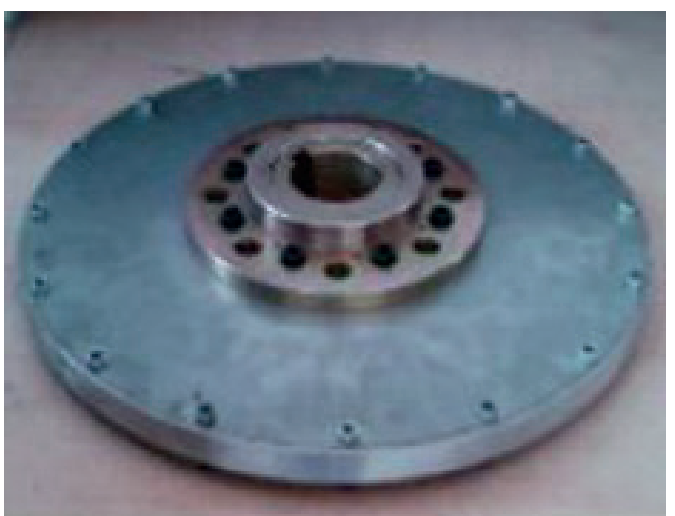

Gambar 5.

Rotor dengan bahan besi lunak Sumber: An Axial-Flux Permanent Magnet (AFPM) Generator for Defence Applications Paradigm Shift in Electrical Machine, (2011).

Penelitian yang di lakukan oleh Ji Young Lee dengan judul "Design of an Axial Flux Permanent Magnet Generator for a Portable Hand Crank Generating System" menggunakan rotor dari bahan SMC-somaloy 700-1P [6].

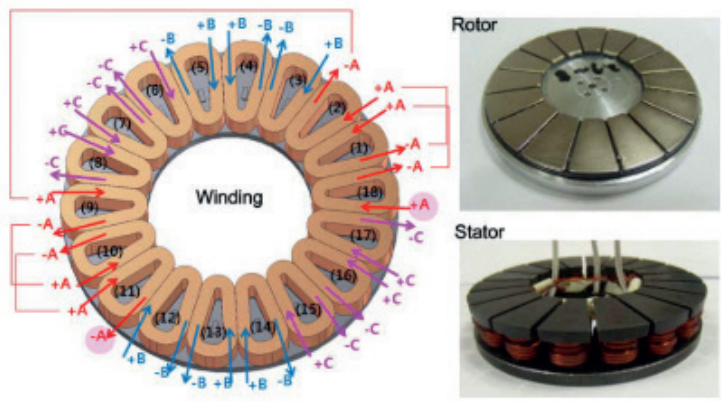

Gambar 6.

Kontruksi rotor dan stator dengan bahan SMCsomaloy $700-1 \mathrm{P}$

Sumber: Design of an Axial Flux Permanent Magnet Generator for a Portable Hand Crank Generating System, (2012).

Biaya penelitian merupakan hal yang sangat penting dalam penelitian [12]. Jumlah biaya yang diperlukan tergantung pada tingkat profesionalisme tenaga peneliti dan pendukungnya, tingkat risiko kegiatan yang dilakukan, jarak tempat penelitian dengan tempat peneliti serta lamanya penelitian dilakukan. Biaya penelitian pada umumnya $60 \%$ digunakan untuk tenaga, dan $40 \%$ untuk penunjang seperti bahan, alat, transport, dan sewa alat-alat komputer. Biaya penelitian pada 
umumnya ditanggung peneliti atau mahasiswa yang melakukan penelitian.

Dari uraian tentang beberapa penelitian yang telah di lakukan para peneliti sebelumnya tentang desain pembuatan berbagai jenis generator aksial seperti tersebut di atas rata-rata menggunakan bahan-bahan logam seperti besi lunak, SMC-somaloy700-1P, dan inti dengan laminasi. Penggunaan bahan-bahan logam tentunya akan membuat proses pembuatan cakram akan semakin rumit dan harus menggunaan alat-alat seperti mesin cnc, mesin pres logam, mesin cor logam. Penggunaan mesin-mesin cetak logam berat tersebut akan menambah biaya penelitian semakin banyak, yang pada ahirnya biaya penelitian tersebut di bebankan kepada mahasiswa atau peneliti.

Bahan non logam yang cukup kuat dan mudah dalam pengerjaan desainya untuk level penelitian antara lain akrilik dan kayu. Akrilik adalah thermoplastik yang ringan, kaku, dan tahan pada perubahan cuaca. Akrilik secara dimensional stabil dan tahan terhadap kerusakan, mudah untuk di gergaji atau dikerjakan dengan mesin. Lembar akrilik tidak sekaku kaca atau logam, tetapi lebih kaku dari banyak jenis plastik lainya seperti asetat, polikarbonat atau vinil. Akrilik mampu menahan beban tekan 750 sampai 1500 psi pada suhu [7].

Triplek merupakan salah satu jenis dari kayu lapis dan merupakan hasil dari produk olahan kayu, terbuat dari lembaran-lembaran kayu tipis yang di rekatkan menjadi satu kemudian di pres dengan tekanan tinggi dan di lem menggunakan lem khusus menjadi satu [8]. Triplek berpotensi sebagai bahan yang dapat digunakan untuk membuat suatu obyek karena material yang dihasikan dari olahan kayu.

Dari pemaparan uraian di atas, dapat dirumuskan beberapa masalah antara lain adakah hubungan antara penggunaan akrilik dan kayu terhadap biaya penelitian? dan adakah pengaruh cakram yang terbuat dari akrilik dan kayu terhadap tegangan keluaran dari generator aksial?

Tujuan dari penelitian ini adalah untuk mencari bahan alternative lain dari jenis non- logam, yang lebih murah harga bahanya, mudah pencarianya, dan mudah dalam proses pembuatanya, sehingga biaya untuk penelitian dapat ditekan lebih rendah. Bahan yang digunakan dalam penelitian ini adalah akrilik dan kayu. Peneliti mencoba membandingkan pengaruh antara cakram yang terbuat dari bahan akrilik dengan cakram yang terbuat dari kayu terhadap tegangan keluaran generator dan dari segi ekonomis.

\section{Gaya gerak listrik induksi}

Generator aksial bekerja berdasarkan hukum faraday yang secara matematis dirumuskan:

$E i=N \frac{\Delta \Phi}{\Delta t}$

dengan $\mathrm{Ei}=$ tegangan induksi $($ Volt $), \mathrm{N}=$ jumlah lilitan, $\Phi=$ fluks magnet $(\mathrm{Wb}), \Delta \mathrm{t}=$ waktu (s). Persamaan faraday ini digunakan sebagai acuan pokok untuk mengetahui variabel yang berpengaruh terhadap tegangan keluaran generator aksial.

\section{Permeabilitas}

Permeabilitas atau daya hantar magnet adalah kemampuan suatu bahan atau media untuk dilalui oleh fluks magnet. Permeabilitas magnetik, dilambangkan dengan simbol adalah sebuah istilah yang digunakan untuk mengekspresikan hubungan antara induksi magnetik (B) dan gaya magnetisasi $(\mathrm{H})$ dalam suatu bahan di bawah kondisi tertentu, atau dengan bahasa sederhananya adalah rasio induksi ke gaya magnetisasi. Permeabilitas magnetik absolut di rumuskan sebagai berikut:

$\mu=B / H$

Permeabilitas relatif adalah rasio permeabilitas material terhadap ruang hampa, atau dapat di definisikan sebagai rasio permeabilitas material terhadap konstanta magnetik. Pada penelitian ini digunakan teori permeabilitas karena peneliti akan membandingkan pengaruh dua bahan cakram yang berbeda terhadap tegangan generator. Tegangan generator salah satunya tergantung pada kekuatan induksi magnetik yang terletak 
pada cakram. Magnet permanen yang terletak pada cakram ini medan magnetnya sebagian terhalang oleh lempeng cakram, di mana medan magnet harus bergerak dari kutub utara ke kutub selatan menembus melewati bahan cakram yang memiliki permeabilitas yang berbeda.

\section{Metode}

Pada penelitian ini digunakan metode penelitian eksperimental. Penelitian eksperimental adalah suatu metode penelitian yang digunakan untuh mencari pengaruh variabel bebas terhadap variabel terikat dalam kondisi yang terkendalikan [9]. Variabel bebas merupakan variabel yang mempengaruhi atau menjadi sebab perubahanya atau timbulnya variabel terikat. Variabel terikat merupakan variabel yang di pengaruhi atau yang menjadi akibat karena adanya variabel bebas. Pada penelitian ini jenis bahan cakram akrilik dan kayu sebagai variabel bebas. Sedangkan variabel terikat pada penelitian ini adalah tegangan keluaran generator.

Tabel 4 .

Alat dan Bahan Digunakan dalam Penelitian

\begin{tabular}{l|l}
\hline \multicolumn{1}{c}{ Alat } & \multicolumn{1}{c}{ Bahan } \\
\hline Multimeter digital AIMO MS8211 & Magnet neodium tipe N52 ukuran $3 \mathrm{~cm} \times 5 \mathrm{~cm} \times 1 \mathrm{~cm}$. \\
\hline Digital Photo Tachometer DT 2234C & Akrlilik diameter $30 \mathrm{~cm}$ dengan tebal $1 \mathrm{~cm}$. \\
\hline Rangkaian dimer 2000 watt. & Triplek dengan diameter $30 \mathrm{~cm}$ dan tebal $1 \mathrm{~cm}$. \\
\hline Motor AC 220 V 100 watt. & Kawat lilitan diameter 0,5mm. \\
\hline Bor listrik 550 watt. & Lem PVC. \\
\hline Gergaji listrik 450 watt. & Gear. \\
\hline Bor obeng Makita. & Mur dan baut ukuram 3mm. \\
\hline Solder listrik 40 watt. & Besi kerangka tipe L tebal $3 \mathrm{~mm}$. \\
\hline Tenol. & Poros as 10 mm. \\
\hline Tang potong. & Karet streng. \\
\hline Tang jepit. & Selotip bakar. \\
\hline & Kabel. \\
\hline & Jepit buaya. \\
\hline
\end{tabular}

- Perancangan Kerangka

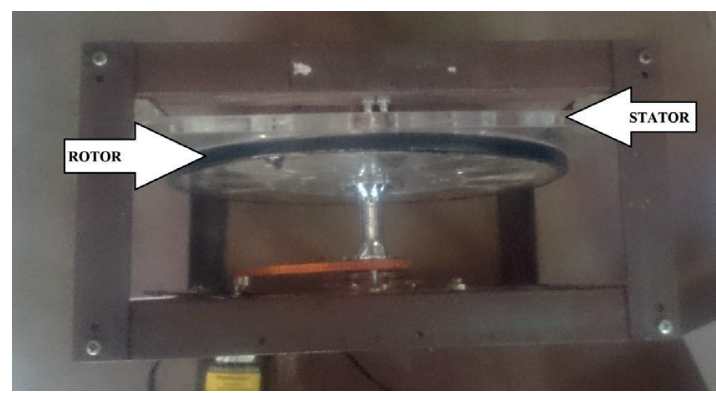

Gambar 7.

Kerangka Generator Axial Tampak Atas Sumber: Dokumentasi pribadi

Desain utama dari kerangka generator seperti tampak pada gambar di atas menggunakan besi tipe $\mathrm{L}$ dengan tebal $3 \mathrm{~mm}$, dengan dimensi panjang $33 \mathrm{~cm}$, lebar $17 \mathrm{~cm}$ dan tinggi $33 \mathrm{~cm}$. Poros as menggunakan besi dengan diameter $10 \mathrm{~mm}$, pada salah satu ujung sisinya dihubungkan dengan roda gigi dan sisi yang lain dihubungkan dengan cakram rotor. Roda gigi dihubungkan menggunakan karet streng ke dinamo yang berfungsi sebagai penggerak utama. Badan dinamo dihubungkan dengan kerangka menggunakan dua buah mur baut. Sedangkan bagian stator di hubungkan dengan kerangka utama generator menggunakan mur baut pada keempat ujung sikunya. 


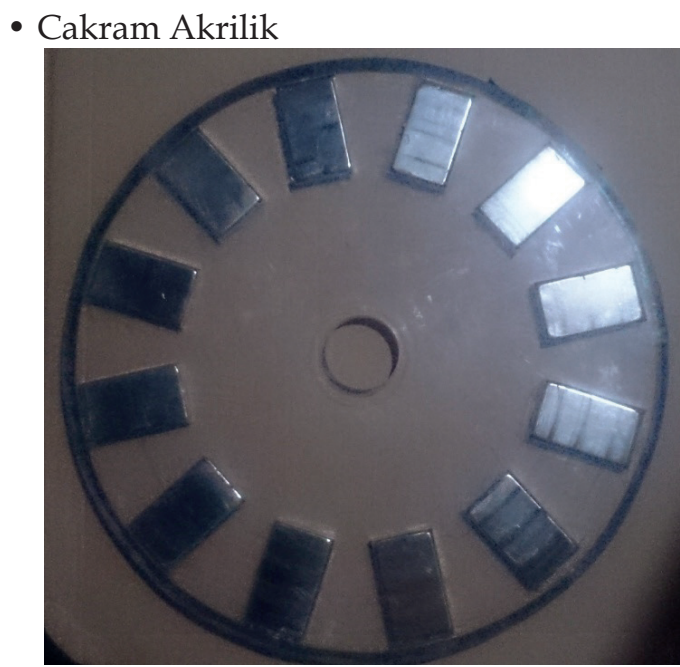

Gambar 8.

Cakram akrilik. Sumber: Dokumentasi pribadi

Cakram rotor seperti di tunjukan gambar di atas terbuat dari bahan akrilik dengan tebal $10 \mathrm{~mm}$. Cakram ini memiliki diameter luar 30 $\mathrm{cm}$ dan diameter dalam sebesar $3,5 \mathrm{~cm}$. Pada cakram ini ditanam 6 magnet kutub utara dan 6 mangnet kutub selatan yang disusun secara silang. Jenis magnet yang di gunakan adalah magnet permanent berbahan neodium dengan tipe N52. Pada pusat cakram terdapat lubang dengan diameter $3,5 \mathrm{~cm}$ yang berfungsi untuk menghubungkan cakram dengan poros as. Proses pembuatan dudukan untuk 12 kutub magnet permanen menggunakan software corel draw. Hasil desain dalam corel draw kemudian di gunakan untuk panduan dalam proses laser cuting. Proses pemotongan menggunakan mesin laser memakan waktu 17 menit untuk jenis bahan akrilik dengan tebal $10 \mathrm{~mm}$.

Cakram rotor seperti di tunjukan gambar di atas terbuat dari bahan kayu dengan tebal $10 \mathrm{~mm}$. Cakram ini memiliki diameter luar 30 $\mathrm{cm}$ dan diameter dalam sebesar $3,5 \mathrm{~cm}$. Pada cakram ini ditanam 6 magnet kutub utara dan 6 magnet kutub selatan yang disusun secara silang. Jenis magnet yang di gunakan adalah magnet permanent berbahan neodium dengan tipe N52. Pada pusat cakram terdapat lubang dengan diameter $3,5 \mathrm{~cm}$ yang berfungsi untuk menghubungkan cakram dengan poros as. Proses pembuatan dudukan untuk 12 kutub

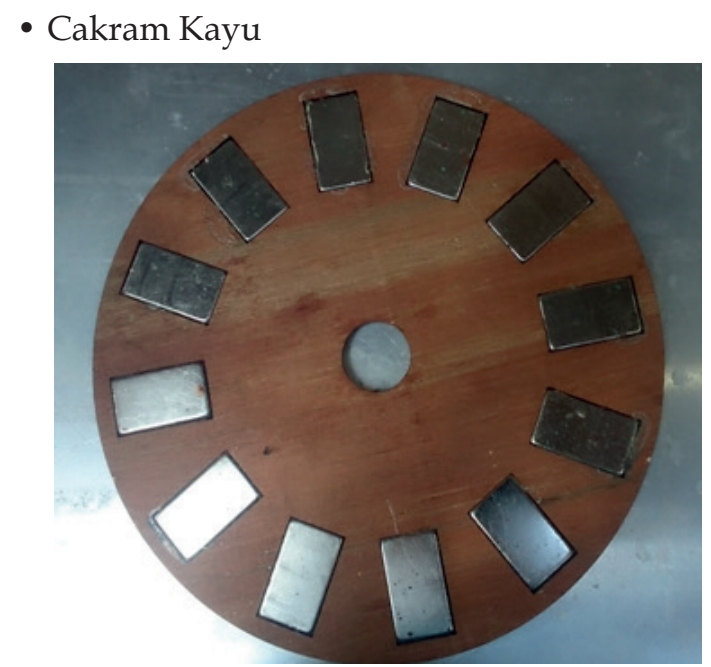

Gambar 9.

Cakram kayu.

Sumber: Dokumentasi pribadi.

magnet permanen menggunakan software corel draw. Hasil desain dalam corel draw kemudian digunakan untuk panduan dalam proses laser cuting. Proses pemotongan menggunakan mesin laser memakan waktu 9 menit untuk jenis bahan kayu dengan tebal $10 \mathrm{~mm}$.

\section{HASIL DAN PEMBAHASAN}

Tabel 5.

Hasil pengujian tegangan keluaran pada cakram akrilik dan cakram kayu.

\begin{tabular}{l|l|l|l}
\hline \multirow{2}{*}{ No } & \multirow{2}{*}{ RPM } & \multicolumn{2}{c}{ K Out (volt) } \\
\cline { 3 - 4 } \multicolumn{1}{c}{} & \multicolumn{1}{c}{ Kayu } & \multicolumn{1}{c}{ Akrilik } \\
\hline 1 & 90 & 3,6 & 3,89 \\
\hline 2 & 151 & 6,45 & 6,27 \\
\hline 3 & 202 & 8,55 & 8,56 \\
\hline 4 & 248 & 10,63 & 10,2 \\
\hline 5 & 313 & 13,46 & 12,6 \\
\hline 6 & 350 & 14,88 & 14,9 \\
\hline 7 & 400 & 17,39 & 16,4 \\
\hline 8 & 450 & 19,30 & 18,7 \\
\hline 9 & 500 & 21,3 & 20,8 \\
\hline 10 & 550 & 23,5 & 22,6 \\
\hline 11 & 602 & 25,6 & 25,2 \\
\hline 12 & 650 & 27,7 & 27,7 \\
\hline 13 & 709 & 30,2 & 28 \\
\hline$\Sigma$ & & 22,56 & 215,82 \\
\hline $\bar{x}$ & & 17,2 & 16,6 \\
\hline
\end{tabular}


Pengujian dilakukan dengan memutar generator dengan menggunakan dinamo. Putaran dinamo divariasikan menggunakan rangkaian dimmer sesuai dengan nilai RPM di tabel 5. Pengukuran RPM menggunakan tachometer digital sedangkan pengukuran tegangan keluaran di ukur menggunakan multimeter digital. Dari hasil pengukuran terlihat bahwa nilai tegangan keluaran pada cakram yang terbuat dari kayu tegangan rataratanya sebesar 17,2 volt. Sedangkan tegangan keluaran rata-rata pada cakram yang terbuat dari akrilik adalah sebesar 16,6 volt. Tegangan keluaran dari cakram kayu rata-ratanya lebih besar 0,6 volt lebih tinggi dari tegangan ratarata cakram akrilik.

Dari data tegangan keluaran pada tabel 4 di atas terlihat bahwa tegangan keluaran dari generator aksial dengan cakram yang terbuat dari triplek memiliki rata-rata tegangan 17,2 volt atau lebih besar dari rata-rata tegangan cakram akrilik. Hal ini berarti bahwa triplek mempunyai permeabilitas magnet yang lebih besar dari akrilik karena permeabilitas lebih besar, maka medan magnet yang diinduksikan ke bagian kumparan lebih kuat. Berdasarkan hukum faraday pada persamaan satu maka jika jumlah lilitan (N) konstan, waktu (t) konstan dan medan magnet menguat maka tegangan induksi akan naik.

Pada cakram yang terbuat dari bahan akrilik, tegangan rata-rata keluaran sebesar 16,6 volt, atau lebih kecil dari tegangan keluaran dari cakram yang terbuar dari triplek. Hal ini menunjukan bahwa permeabilitas magnetik dari bahan akrilik lebih kecil dari permeabilitas magnetik bahan triplek. Berdasarkan hukum faraday pada persamaan satu, maka dalam keaadaan jumlah lilitan $(\mathrm{N})$ konstan, waktu (t) konstan dan medan magnet melemah sehingga tegangan induksi juga akan mengecil.

Tabel 6.

Perbandingan Biaya Pembuatan Cakram Akrilik dan Cakram Kayu.

\begin{tabular}{l|l|l|l|l|l|l}
\hline No & \multicolumn{1}{|c|}{ Bahan } & P x L (cm) & Tebal $(\mathbf{m m})$ & Harga $(\mathbf{R p})$ & Laser Cuting (Rp) & \multicolumn{1}{c}{ Total } \\
\hline 1 & Akrilik & $30 \times 30$ & 10 & 100.000 & 51.000 & 151.000 \\
\hline 2 & Kayu & $30 \times 30$ & 10 & 3.750 & 45.000 & 48.750 \\
\hline
\end{tabular}

Dari tabel di atas, terlihat bahwa harga akrilik dengan ukuran $30 \mathrm{~cm} \times 30 \mathrm{~cm}$ dengan tebal $10 \mathrm{~mm}$ sebesar 100.000 rupiah, sedangakan untuk harga kayu dengan ukuran $30 \mathrm{~cm} \times 30 \mathrm{~cm}$ lebih murah yaitu sebesar 3.750 rupiah. Untuk proses laser cuting akrilik memakan biaya 51.000 rupiah sedangkan kayu 45.000 rupiah. Total biaya pembuatan untuk satu cakram akrilik sebesar 151.000 rupiah, sedangkan biaya total pembuatan cakram kayu adalah 48.750 rupiah. Biaya pembuatan cakram kayu lebih murah dari pembuatan cakram akrilik dengan perbandingan 1:3.

Dari hasil pengamatan grafik di atas terlihat bahwa tegangan keluaran dari cakram yang terbuat dari kayu pada $90 \mathrm{rpm}$ sampai $202 \mathrm{rpm}$ tegangan masih sama antara cakram kayu dengan cakram akrilik, melewati 202 rpm tegangan keluaran dari cakram kayu

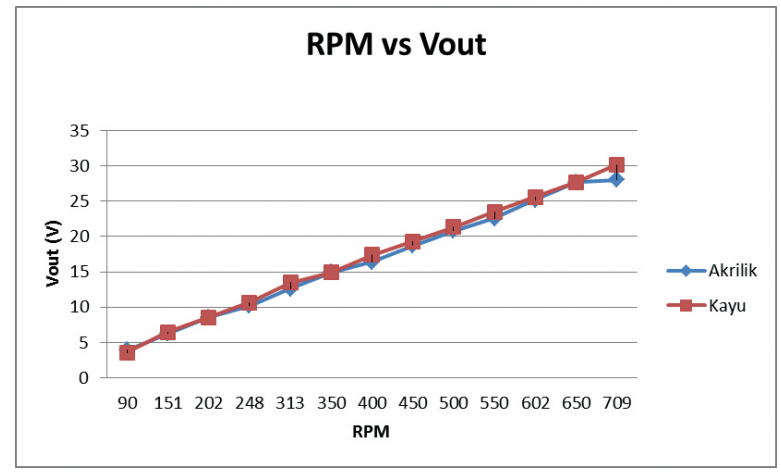

Gambar 10.

Grafik perbandingan tegangan keluaran cakram kayu dan akrilik.

mulai lebih tinggi dari tegangan keluaran cakram yang terbuat dari akrilik. Pada 709 rpm tegangan cakram kayu lebih tinggi 2,2 volt dari tegangan cakram akrilik. 


\section{SIMPULAN}

Dari hasil pengukuran volt meter tegangan keluaran dari generator aksial dengan bahan cakram yang terbuat dari kayu rata-rata sebesar 17,2 volt. Sedangkan tegangan ratarata keluaran generator untuk cakram yang terbuat dari akrilik adalah 16,6 volt. Cakram dari kayu memiliki tegangan keluaran ratarata lebih tinggi 0,6 volt dari cakram akrilik. Hal ini berarti hambatan terhadap medan magnet pada kayu lebih kecil dari hambatan medan magnet pada bahan akrilik. Selain unggul dari segi besarnya tegangan keluaran bahan kayu juga memiliki keuntungan dari segi biaya pembuatan, di mana untuk harga akrilik ukuran $30 \mathrm{~cm} \times 30 \mathrm{~cm}$ adalah 100.000 dengan biaya pemotongan 51.000 rupiah sedangkan untuk harga kayu ukuran $30 \mathrm{~cm} x$ $30 \mathrm{~cm}$ adalah 3.750 rupiah dengan biaya potong 45.000 rupiah. Dari sisi waktu pembuatan juga lebih cepat di mana kayu membutuhkan waktu 9 menit untuk proses laser cuting sedangkan akrilik membutuhkan waktu 17 menit. Dengan demikian bahan kayu dapat digunakan sebagai alternatif bahan untuk penelitian dalam membuat cakram rotor yang murah dan memiliki hambatan terhadap fluks magnet yang lebih kecil dari bahan akrilik.

\section{DAFTAR PUSTAKA}

[1] Jacek F. Gieras, Rong-Jie Wang, Maarten J. Kamper, "Axial Flux Permanent Magnet Brushless Machine" 2004.

[2] K. Latoufis, K. Troullaki, T. Pazios, and N. Hatziargyriou, "Design of Axial Flux Permanent Magnet Generators Using Various Magnetic Materials in Locally Manufactured Small Wind Turbines."2016.
[3] Z. Goryca, "Generators with permanent magnets used in small wind power plants," pp. 7-10, 2015.

[4] M. Chirca, S. Breban, C. A. Oprea, and M. M. Radulescu, "Analysis of Innovative Design Variations for Permanent-Magnet Generators in Micro-Wind Power Applications," pp. 385-389, 2014.

[5] V. V. Parlikar, P. M. Kurulkar, K. P. Rathod, and P. Kumari, "An Axial-Flux Permanent Magnet (AFPM) Generator for Defence Applications-Paradigm Shift in Electrical Machine.," Int. J. Electr. Power Eng., vol. 3, no. 1, pp. 33-37, 2012.

[6] J. Y. Lee, D. H. Koo, S. R. Moon, and C. K. Han, "Design of an axial flux permanent magnet generator for a portable hand crank generating system," IEEE Trans. Magn., vol. 48, no. 11, pp. 2977-2980, 2012.

[7] CYRO, "Physical Properties of Acrylite FF Acrylic Sheet." 2001.

[8] A. Ramadhan and U. M. Buana, "EKSPLORASI FISIK MATERIAL TRIPLEK," no. March, 2017.

[9] J. Sarwono, "Metode Penelitian Kuantitatif \& Kualitatif," dalam Graha Ilmu, 2006, pp. 1-306. 